\title{
PELAKSANAAN PERJANJIAN ANTARA AGEN DENGAN PEMILIK PRODUK UNTUK DI PASARKAN KEPADA MASYARAKAT
}

\author{
Deny Slamet Pribadi
}

\author{
Dosen Fakultas Hukum Universitas Mulawarman Samarinda
}

\begin{abstract}
ABSTRAK
Dalam perjanjian keagenan yang dilakukan secara tertulis tentunya memiliki kekuatan hukum yang mengikat bagi kedua belah pihak, jadi masing-masing pihak harus memenuhi prestasi sesuai dengan yang diperjanjikan. Bagi pihak pertama harus memberikan ganti rugi atau pembayaran tranportation fee kepada pihak kedua atas jasa pengangkutan dari supply poin ke konsumen mengikuti ketentuan yang telah ditetapkan oleh pihak pertama, sedangkan bagi pihak kedua harus memenuhi kewajibannya dan menagih jasa tranportation fee. Semuanya itu merupakan hubungan hukum yang terjadi sesuai dengan perjanjian yang dibuat. Dalam setiap perjanjian keagenan, sering terdapat suatu kesepakatan mengenai biaya transportasi yang akan diberikan oleh perusahaan pemilik barang produk dan kadang yang terjadi banyak kasus belum memberikan biaya tersebut kepada pihak agen.
\end{abstract}

Kata Kunci : Keagenan, Perjanjian, Perusahaan.

\section{PENDAHULUAN}

Perjanjian keagenan dan distributor adalah merupakan bagian dari perjanjian bernama diluar KUHPerdata (Dagang). Agen adalah suatu perusahaan yang bertindak atas nama prinsipil, karena agen tidak melakukan pembelian dari prinsipil. Barangbarang tetap menjadi milik prinsipil sampai diselesaikannya proses penjualan melalui penyaluran atau penyampaian barang kepada pihak konsumen. Sedangkan distributor adalah suatu badan usaha yang membeli barang-barang dari prinsipil atas biaya mereka, menjualnya kepada konsumen di bawah wilayah pemasaran yang telah disepakati bersama.

Dalam setiap perjanjian keagenan, sering terdapat suatu kesepakatan mengenai biaya transportasi yang akan diberikan oleh perusahaan pemilik barang produk dan kadang yang terjadi banyak kasus belum memberikan biaya tersebut kepada pihak agen.

Dalam perjanjian keagenan yang dilakukan secara tertulis tentunya memiliki kekuatan hukum yang mengikat bagi kedua belah pihak, jadi masing-masing pihak harus memenuhi prestasi sesuai dengan yang diperjanjikan. Bagi pihak pertama harus memberikan ganti rugi atau pembayaran tranportation fee kepada pihak kedua atas jasa pengangkutan dari supply poin ke konsumen mengikuti ketentuan yang telah ditetapkan oleh pihak pertama, sedangkan bagi pihak kedua harus memenuhi kewajibannya dan menagih jasa tranportation fee. Semuanya itu merupakan hubungan hukum yang terjadi sesuai dengan perjanjian yang dibuat. 
Seperti perjanjian kerjasama pada umumnya, ketika kedua belah pihak telah menyetujui untuk melakukan kerjasama berdasarkan atas perjanjian yang dibuat maka kedua belah pihak telah terikat secara hukum sesuai dengan Pasal 1338 KUHPerdata. Apabila terdapat salah satu pihak yang tidak melakukan hal seperti yang diperjanjikan, maka pihak tersebut telah melanggar isi perjanjian yang telah disetujuinya, atau dapat kita sebut sebagai wanprestasi.

\section{RUMUSAN MASALAH}

Berdasarkan uraian diatas, maka yang menjadi permasalahan dalam penulisan ini adalah "Bagaimana pelaksanaan perjanjian antara agen dengan perusahaan pemilik produk sehingga tidak merugikan kedua belah pihak"

\section{PEMBAHASAN}

Suatu perjanjian adalah suatu perbuatan dengan mana satu orang atau lebih mengikatkan dirinya terhadap satu orang atau lebih lainnya, perjanjian harus dibuat dengan cuma-cuma atau atas beban. Perjanjian dengan cuma-cuma adalah suatu perjanjian dengan mana pihak yang satu memberikan suatu keuntungan kepada pihak yang lain, tanpa menerima suatu manfaat bagi dirinya sendiri, sedangkan perjanjian atas beban adalah suatu perjanjian yang mewajibkan masing-masing pihak memberikan sesuatu atau tidak berbuat sesuatu.

Untuk sahnya suatu perjanjian harus memenuhi empat syarat, yaitu sepakat mereka yang meningkatkan dirinya, kecakapan untuk membuat suatu perikatan, suatu hal tertentu, dan dikarenakan oleh suatu sebab yang halal.

Agen adalah suatu perusahaan yang bertindak atas nama prinsipil, karena agen tidak melakukan pembelian dari prinsipil. Barang-barang tetap menjadi milik prinsipil sampai diselesaikannya proses penjualan melalui penyaluran atau penyampaian barang kepada pihak konsumen. Sedangkan distributor adalah suatu badan usaha yang membeli barang-barang dari prinsipil atas biaya mereka, menjualnya kepada konsumen di bawah wilayah pemasaran yang telah disepakati bersama. ${ }^{1}$

Dalam penjualan dan penyaluran ini, perusahaan pemilik produk telah melakukan perjanjian dengan agen yang mana perjanjian tersebut disebut dengan perjanjian keagenan itu sendiri menurut Pasal 1313 KUHPerdata, yaitu: "Perjanjian adalah suatu perbuatan dengan mana satu orang atau lebih mengikatkan dirinya terhadap satu orang atau lebih lainnya". ${ }^{2}$ Selanjutnya menurut R. Subekti memberikan pengertian dari perjanjian yang berbunyi "Suatu perjanjian adalah suatu peristiwa dimana seseorang berjanji kepada orang lain atau dimana dua orang itu saling berjanji untuk melaksakan sesuatu hal". 3 Dari dua definisi tersebut, maka dapat ditarik suatu kesimpulan bahwa perjanjian merupakan hubungan hukum antara dua orang atau

\footnotetext{
${ }^{1}$ Mariam Darus Badrulzaman, ,Aneka Hukum Bisnis, Alumni, Bandung, 2005, Hal. 31.

${ }^{2}$ R. Subekti dan R. Tjitrosudibyo, Kitab Undang-undang Hukum Perdata, Pradya Paramitha, Jakarta, 1994, Hal. 282.

${ }^{3}$ R. Subekti, Hukum Perjanjian, Intermasa, Jakarta, 1985, Hal. 1.
} 
lebih yang bersifat timbal balik dan mengikat para pihak. Hubungan hukum menurut Mariam Darus Badrulzaman adalah:

"Hubungan yang terjadi diantara pihak yang membuat perjanjian sehingga timbul hak dan kewajiban terhadap pihak-pihak yang membuat perjanjian. “ 4

Mengacu pada perjanjian di atas maka terdapat pihak-pihak yang melakukan perjanjian, antara lain pihak pemilik produk dan pihak agen. Dimana pihak agen telah terikat untuk melaksanakan segala yang telah di perjanjikan dalam perjanjian.

Sahnya suatu perjanjian harus memenuhi syarat-syarat yang ditetapkan dalam Pasal 1320 KUHPerdata yang menyatakan untuk sahnya perjanjian diperlukan empat syarat:

1. Sepakat mereka yang mengikatkan dirinya;

2. Kecakapan untuk membuat suatu perikatan;

3. Suatu hal tertentu;

4. Suatu sebab yang halal. ${ }^{5}$

Sepakat mereka yang mengikatkan dirinya merupakan asas esensial yang paling mendasar pada hukum perjanjian. Asas ini dinamakan juga dengan asas konsensualitas.

Menurut Abdul Kadir Muhammad, asas konsensualitas adalah :

"Perjanjian itu terjadi (ada) sejak tercapainya kata sepakat antara pihak-pihak. Dengan kata lain perjanjian itu sudah sah dan mempunyai akibat hukum sejak saat tercapainya kata sepakat antara pihak-pihak mengenai pokok perjanjian." 6

Jadi asas konsensualitaslah yang menentukan saat lahirnya suatu perjanjian dan mengandung suatu pengertian akan kemauan para pihak untuk saling berprestasi, serta dengan adanya kemauan untuk saling mengikatkan diri.

Perjanjian yang dibuat dan telah memenuhi syarat-syarat dalam Pasal 1320 KUHPerdata menjadikan para pihak terikat oleh ketentuan dalam Pasal 1338 ayat (1) KUHPerdata yang menyatakan:

"Semua perjanjian yang dibuat secara sah dan berlaku sebagai undang-undang bagi mereka yang membuatnya."7

Dalam perjanjian keagenan yang dilakukan oleh perusahaan pemilik produk dan agen seharusnya terdapat pasal yang menegaskan mengenai fee dalam perjanjian keagenannya yang berbunyi:

"Sebagai kompensasi atas jasa penjualan barang/produk maka pihak kedua mendapatkan margin dan atas jasa penjualan produk dari supply barang ke konsumen mendapatkan fee dari pihak pertama."

Bagi pihak pertama harus memberikan ganti rugi atau pembayaran fee kepada pihak kedua atas jasa penjualan produk dari supply point ke konsumen mengikuti ketentuan yang telah ditetapkan oleh pihak pertama, sedangkan bagi pihak kedua harus memenuhi kewajibannya dan menagih jasa fee. Semuanya itu merupakan hubungan hukum yang terjadi sesuai dengan perjanjian yang dibuat.

\footnotetext{
${ }^{4}$ Mariam Darus Badrulzaman, Op.Cit., 2005, Hal. 3

${ }^{5}$ R. Subekti dan R. Tjitrosudibyo, Op.Cit., 1994, Hal. 283.

${ }^{6}$ Abdul Kadir Muhammad, Hukum Perikatan, Citra Aditya Bakti, Bandung, 1990, Hal. 85.

${ }^{7}$ Loc. Cit., Hal. 285.
} 
Namun adanya kejadian mengenai kelalaian dalam pembayaran fee yang mengakibatkan perjanjian menjadi cacat, dimana pihak pertama perusahaan pemilik produk tidak memenuhi prestasinya sebagaimana mestinya. Pihak kedua merasa dirugikan akibat kelalaian tersebut dan dapat mengajukan tuntutan kepada pihak pertama.

Menurut M.Yahya Harahap memberikan pengertian wanprestasi:

"Wanprestasi adalah pelaksanaan kewajiban yang tidak tepat waktunya atau dilaksanakan tidak menurut selayaknya. Kalau begitu seorang debitur disebut dan berada dalam keadaan wanprestasi apabila melakukan pelaksanaan dari prestasi perjanjian telah lalai sehingga terlambat dari jadwal waktu yang ditentukan atau dalam melaksanakan prestasi selanjutnya (selayaknya)." 8

Sedangkan menurut R. Subekti bahwa wanprestasi dibagi menjadi empat macam:

1. Tidak melakukan apa yang disanggupinya akan dilaksanakan;

2. Melakukan apa yang dijanjikan tetapi tidak sebagaimana dijanjikan;

3. Melakukan apa yang diperjanjikan tetapi terlambat;

4. Melakukan sesuatu yang menurut perjanjian tidak boleh dilakukan. ${ }^{9}$

Dari dua definisi di atas maka dapat disimpulkan bahwa wanprestasi merupakan kelalaian pelaksanaan kewajiban oleh salah satu pihak yang telah terikat dalam suatu perjanjian yang sah. Yang termasuk wanprestasi yang dilakukan oleh pemilik produk adalah tidak melakukan apa yang disanggupinya akan dilaksanakan. Dengan adanya wanprestasi dari salah satu pihak, maka akan membawa akibat hukum, yaitu:

1. Membayar kerugian yang diderita oleh kreditur;

2. Pembatalan perjanjian;

3. Peralihan resiko;

4. Membayar biaya perkara apabila diperkarakan dimuka pengadilan. ${ }^{10}$

Jadi terhadap pihak perusahaan pemilik produk yang telah melakukan wanprestasi atau ingkar janji dapat diberikan sanksi-sanksi tersebut, akibat dari perbuatannya yang mendatangkan kerugian bagi agen.

Seperti yang telah diketahui dalam kehidupan sehari-hari perjanjian bukan merupakan hal yang dianggap tabu, bahkan hampir semua orang telah melakukan perjanjian baik tertulis maupun lisan. Perjanjian tersebut memberikan konsekuensi hukum bahwa dalam suatu perjanjian akan selalu ada dua pihak dimana satu pihak adalah pihak yang wajib melaksanakan prestasi dan pihak lainnya adalah pihak yang berhak atas prestasi tersebut.

Dengan disepakatinya suatu perjanjian antara pihak perusahaan pemilik produk dengan agen, maka menimbulkan kewajiban-kewajiban dari masing-masing pihak untuk melaksanakan prestasi. Kewajiban ini bersifat mengikat karena sesuai dengan asas yang terdapat dalam hukum perdata, bahwa dikatakan suatu perjanjian yang dibuat secara sah akan berlaku sebagai undang-undang bagi yang membuatnya.

Dalam perjanjian keagenan yang dilakukan secara tertulis memiliki kekuatan hukum yang mengikat bagi kedua belah pihak, jadi masing-masing pihak harus memenuhi prestasi sesuai dengan yang diperjanjikan. Terjadinya kelalaian dalam

\footnotetext{
${ }^{8}$ Yahya Harahap, Segi-segi Hukum Perikatan, Alumni, Bandung, 1986, Hal. 60.

${ }^{9}$ R. Subekti, Aneka Perjanjian, Intermasa, Jakarta, 1987, Hal. 45.

${ }^{10}$ Ibid., Hal. 45.
} 
pembayaran fee yang mengakibatkan perjanjian menjadi cacat, dimana pihak pertama tidak memenuhi prestasinya sebagaimana mestinya. Pihak kedua merasa dirugikan akibat kelalaian tersebut dan dapat mengajukan tuntutan kepada pihak pertama.

Karena kelalaian dalam pembayaran fee tersebut pihak pertama dapat dimintai pertanggungjawaban. Pihak pertama harus membayar fee dan kerugian yang diakibatkan kesalahan tersebut. Apabila pihak pertama tidak bersedia bertanggung jawab maka dapat dituntut atau diajukan ke pengadilan.

\section{Hak dan Kewajiban Antara Para Pihak}

Dibuatnya perjanjian antara perusahaan pemilik produk dengan agen maka akan menimbulkan hak dan kewajiban diantara para pihak yang membuat perjanjian. Sebagaimana diketahui bahwa perjanjian menurut Prof. R. Subekti, SH adalah:

"Suatu perjanjian adalah suatu peristiwa dimana seseorang berjanji kepada orang lain atau dimana dua orang itu saling berjanji untuk melaksanakan suatu hal."11

Kehendak untuk melaksanakan sesuatu yang sudah diperjanjikan ini merupakan suatu wujud dari pemenuhan prestasi dengan itikad baik. Hal ini sesuai dengan ketentuan-ketentuan pada Pasal 1338 KUHPerdata, yang berbunyi:

"Perjanjian diartikan sebagai suatu perhubungan hukum mengenai harta benda kekayaan antara 2 (dua) pihak, dalam mana 1 (satu) pihak berjanji atau dianggap berjanji untuk melakukan suatu hal atau untuk tidak melakukan suatu hal, sedangkan pihak lain berhak menuntut pelaksanaan perjanjian itu."

Perjanjian yang telah dibuat antara perusahaan pemilik produk dengan agen adalah merupakan suatu perjanjian keagenan. Dengan disepakatinya isi dari perjanjian tersebut dan telah membubuhkan tanda tangan pada surat perjanjian maka para pihak telah terikat.

Hak dan kewajiban para pihak yang tercantum dalam surat perjanjian antara perusahaan pemilik produk dengan agen dapat dijelaskan sebagai berikut:

a. Hak dan Kewajiban Perusahaan Pemilik Produk

1) Memiliki hak penuh untuk:

a) Berhak memantau dan memberi petunjuk kepada agen sehubungan dengan perjanjian, termasuk tata kerja dan administrasi, yang meliputi administrasi penjualan produk.

b) Perusahaan pemilik produk setiap saat berhak memeriksa baik secara teknis dan atau secara administratif terhadap kelengkapan dan peralatan milik agen yang dipergunakan untuk pemasaran produknya.

c) Perusahaan pemilik produk berhak menolak untuk merubah bentuk dan isi dari produknya yang diserahkan kepada agen apabila menurut pertimbangan dan penilaian perusahaan pemilik produk pihak agen telah merubah bentuk dan isi produk.

d) Perusahaan pemilik produk berhak menyita produknya yang sudah berada pada agen tanpa memberikan pengganti, apabila menurut pertimbangan dan penilaian perusahaan pemilik produk tersebut tidak sesuai dengan

${ }^{11}$ Ibid., Hal. 45. 
yang sudah distandarkan berdasarkan kualitas dari hasil produk pada perusahaan.

2) Pemilik produk berkewajiban untuk:

a) Memberikan besaran fee atas jasa pengangkutan dan penjualan ke konsumen mengikuti ketentuan yang telah ditetapkan perusahaan.

b) Fee yang diberikan oleh perusahaan pemilik produk kepada agen dihitung berdasarkan realisasi jumlah produk yang dijual agen.

b. Hak dan Kewajiban Agen :

1) Agen memiliki hak penuh untuk :

a) Menagih besaran fee atas jasa penjualan produk ke konsumen mengikuti ketentuan yang ditetapkan oleh perusahaan pemilik produk.

b) Setiap ada perubahan ketentuan penjualan, fee, termaksud mekanisme penagihan yang dilakukan oleh agen akan diberitahukan secara tertulis kepada perusahaan pemilik produk dan tanpa dibuatkan addendum dari isi perjanjian.

2) Agen berkewajiban untuk:

a) Melayani konsumen dengan baik dan sopan.

b) Bekerjasama secara baik dengan perusahaan pemilik produk untuk kelancaran penyaluran dan distribusi produk untuk memenuhi kebutuhan masyarakat.

c) Aktif dan bertanggung jawab dalam pengusahaan dan pelayanan kepada konsumen dan menjaga kelancaran penyaluran produk kepada konsumen serta wajib menjaga citra perusahaan pemilik produk terhadap masyarakat dengan menjamin pelayanan yang memuaskan dan optimal bagi para konsumen.

d) Memenuhi, memperhatikan, melaksanakan ketentuan, dan mematuhi sanksi-sanksi keagenan yang telah ditetapkan oleh perusahaan pemilik produk.

e) Memiliki karyawan yang cukup, terampil dan memperhatikan syaratsyarat keselamatan serta membina karyawannya dengan baik.

f) Bersama dengan karyawannya ikut memberikan penjelasan, penyuluhan mengenai produk serta menanamkan kesadaran safety kepada konsumen.

g) Melengkapi karyawannya dengan indentity card, pakaian seragam, dengan mencantumkan secara jelas nama agen, logo produk dan nama petugas yang bersangkutan.

h) Menyediakan lokasi untuk penyimpanan produk atau gudang penyimpanan untuk showroom/outlet serta memenuhi persyaratan baik ditinjau dari segi kegunaan, komersial, keselamatan dan lingkungan maupun keamanannya. Memiliki showroom/outlet dengan alamat tetap berada dilokasi pemasarannya.

i) Memiliki kendaraan operasional (jika diperlukan sesuai dengan ketentuan yang ditetapkan oleh perusahaan pemilik produk untuk mengangkut produk sesuai yang ditentukan oleh perusahaan pemilik produk). 
j) Menjamin mutu dan produk yang diserahkan ke konsumen serta melakukan pengawasan terhadap penjualan produk terhadap karyawan agen.

k) Melakukan pemeliharaan atas sarana-sarana yang ada dengan baik sehingga terjamin kelancaran dan kehandalan operasi.

1) Menjaga citra/nama baik perusahaan pemilik produk, dengan menjamin pelayanan yang memuaskan dan optimal bagi konsumen.

Selain dari ada hak dan kewajiban yang diterangkan di dalam surat perjanjian jasa fee juga terdapat penjelasan tentang biaya angkut jasa, pembatasan tanggung jawab, pemutusan jasa.

\section{Akibat Hukum Yang Timbul Bagi PT. Pertamina (Persero) Yang Wanprestasi}

Perjanjian merupakan hal yang utama sebelum melaksanakan kerjasama, karena para pihak telah membuat perjanjian tersebut maka mereka terikat satu sama lainnya dan kedua belah pihak harus mematuhi apa yang telah diperjanjikan seperti halnya menaati sebuah undang-undang.

Untuk sahnya suatu perjanjian diperlukan 4 (empat) syarat, menurut Pasal 1320 KUHPerdata, yang menyebutkan:

1. Sepakat mereka yang mengikat diri;

2. Kecakapan untuk membuat suatu perikatan;

3. Suatu hal tertentu;

4. Suatu sebab yang halal.

Perjanjian tersebut tidak dapat ditarik kembali secara sepihak kecuali jika ada alasan-alasan yang cukup menurut undang-undang. Pelaksanaan perjanjian harus dilakukan dengan itikad baik dan mengindahkan norma-norma kepatuhan, kesusilaan dan juga kebiasaan, seperti yang ditentukan dalam Pasal 1339 KUHPerdata, bahwa:

"Perjanjian-perjanjian tidak hanya mengikat hal-hal yang dengan tegas dinyatakan di dalamnya, tetapi juga untuk segala sesuatu yang menurut sifat perjanjian, harus oleh kepatutan, kebiasaan atau undang-undang”.

Dengan demikian setiap perjanjian dilengkapi oleh aturan undang-undang dan adat kebiasaan disuatu tempat serta kepatutan. Kebiasaan juga merupakan sumber hukum selain undang-undang, sehingga turut menentukan hak dan kewajiban para pihak dalam perjanjian.

Begitu juga dalam perjanjian keagenan, maka kedua belah pihak harus mematuhi perjanjian yang telah dibuat tersebut. Dalam perjanjian perusahaan pemilik produk wajib membayar jasa fee setiap bulan kepada agen. Yang dimaksud dengan pelaksanaan perjanjian atau pemenuhan hak dan kewajiban yang telah diperjanjikan oleh pihak-pihak supaya perjanjian itu mencapai tujuannya. Tujuan itu tidak akan terwujud tanpa dilaksanakan perjanjian tersebut, dengan 
demikian masing-masing pihak harus melaksanakan perjanjian dengan sempurna dan tepat apa yang telah disetujui untuk dilakukan.

Apabila pihak yang wajib melakukan atau memberikan prestasi, dan prestasi itu tidak dipenuhi, dikatakan bahwa pihak tersebut telah wanprestasi. Suatu perbuatan dikatakan atau dikategorikan sebagai wanprestasi menurut M. Yahya Harahap, SH adalah:

"Pelaksanaan kewajiban yang tidak tepat pada waktunya atau dilakukan tidak selayaknya, kalau begitu seseorang debitur dan berada dalam keadaan wanprestasi, apabila dia dalam melakukan pelaksanaan prestasi telah lalai sehingga terlambat dari jadwal yang telah ditentukan atau dalam melaksanakan prestasi tidak menurut sepatutnya atau selayaknya."

Perjanjian yang diadakan oleh perusahaan pemilik produk dengan agen merupakan perjanjian tertulis yang dengan jelas diketahui oleh agen serta akibatnya jika biaya fee tidak dibayar.

Sedangkan menurut R. Subekti bahwa wanprestasi dibagi menjadi empat bagian, yaitu :

1. Tidak melakukan apa yang disanggupi akan dilaksanakannya;

2. Melakukan apa yang dijanjikan tetapi tidak sebagaimana dijanjikan;

3. Melakukan apa yang diperjanjikan tetapi terlambat;

4. Melakukan sesuatu yang menurut perjanjian tidak boleh dilakukan.

\section{Upaya Hukum Yang Dilakukan Agen Terhadap Perusahaan Pemilik Produk Yang Wanprestasi}

Perjanjian dibuat adalah untuk dilaksanakan dan suatu perjanjian akan mencapai tujuannya jika telah dilaksanakan. Dengan demikian jika suatu perjanjian tidak dilaksanakan dengan sepenuhnya maka perjanjian tersebut tidak akan mencapai tujuan seperti yang diharapkan oleh kedua belah pihak yang telah bersepakat dan hal ini akan menimbulkan suatu kerugian yang dapat ditanggung salah satu atau kedua belah pihak. Oleh karena itu kedua belah pihak harus selalu berusaha agar suatu perjanjian yang telah dibuat atas dasar suatu kesepakatan dapat dilaksanakan dengan baik.

Demikian juga perjanjian antara perusahaan pemilik produk dengan agen selalu berusaha agar setiap konsumen dapat terlayani seluruh haknya dengan baik dan puas atas jasa yang diberikan sehingga tidak akan terjadi perbuatan wanprestasi.

Upaya yang dilakukan untuk mengatasi terjadinya wanprestasi antara lain adalah dalam hal ini agen selalu melakukan penagihan terhadap haknya atas pembayaran fee. Walaupun terkadang didalam perjanjian tidak ada perincian mengenai sanksi yang akan diberikan kepada Perusahaan Pemilik Produk apabila fee tidak dibayarkan. Dalam hal ini, perjanjian mengenai keagenan yang dilakukan kedua belah pihak telah merugikan pihak agen karena fee merupakan keuntungan perusahaan tersebut seperti untuk membayar gaji karyawan dan lain sebagainya. Seharusnya dalam perjanjian tersebut ditentukan sanksi yang jelas bagi perusahaan 
pemilik produk apabila melakukan perbuatan wanprestasi, jadi keadilan bagi kedua belah pihak sama.

\section{PENUTUP}

\section{A. Kesimpulan}

Perjanjian merupakan hal yang utama sebelum melaksanakan kerjasama, karena para pihak telah membuat perjanjian tersebut maka mereka terikat satu sama lainnya dan kedua belah pihak harus mematuhi apa yang telah diperjanjikan seperti halnya menaati sebuah undang-undang.

Dengan demikian jika suatu perjanjian tidak dilaksanakan dengan sepenuhnya maka perjanjian tersebut tidak akan mencapai tujuan seperti yang diharapkan oleh kedua belah pihak yang telah bersepakat dan hal ini akan menimbulkan suatu kerugian yang dapat ditanggung salah satu atau kedua belah pihak. Oleh karena itu kedua belah pihak harus selalu berusaha agar suatu perjanjian yang telah dibuat atas dasar suatu kesepakatan dapat dilaksanakan dengan baik.

Demikian juga perjanjian antara perusahaan pemilik produk dengan agen selalu berusaha agar setiap konsumen dapat terlayani seluruh haknya dengan baik dan puas atas jasa yang diberikan sehingga tidak akan terjadi perbuatan wanprestasi.

\section{B. Saran}

Setiap perjanjian dilengkapi oleh aturan undang-undang dan adat kebiasaan di suatu tempat serta kepatutan. Kebiasaan juga merupakan sumber hukum selain undang-undang, sehingga turut menentukan hak dan kewajiban para pihak dalam perjanjian. Begitu juga dalam perjanjian keagenan, maka kedua belah pihak harus mematuhi perjanjian yang telah dibuat tersebut. Dalam perjanjian perusahaan pemilik produk wajib membayar jasa fee setiap bulan kepada agen. Yang dimaksud dengan pelaksanaan perjanjian atau pemenuhan hak dan kewajiban yang telah diperjanjikan oleh pihak-pihak supaya perjanjian itu mencapai tujuannya. Tujuan itu tidak akan terwujud tanpa dilaksanakan perjanjian tersebut, dengan demikian masing-masing pihak harus melaksanakan perjanjian dengan sempurna dan tepat apa yang telah disetujui untuk dilakukan.

\section{DAFTAR PUSTAKA}

\section{Daftar Literatur:}

a. Abdul Kadir Muhammad, Hukum Perikatan, Citra Aditya Bakti, Bandung, 1990.

b. Mariam Darus Badarulzaman, Kompilasi Hukum Perikatan (1), Citra Aditya Bakti, Bandung, 2001.

c. M. Yahya Harahap, Segi-segi Hukum Perjanjian, Alumni, Bandung, 1993. 
d. Ronny Hanitijo Soemitro, Metode Penelitian Hukum, Gahlia Indonesia, Jakarta, 1988.

e. R. Subekti dan TR. Tjirosudibio, KUH Perdata, PT. Pradnya Paramita, Jakarta, 2009.

f. --------------, Hukum perjanjian, Intermasa, Jakarta, 1998.

g. R. Subekti, Aneka Perjanjian, Intermasa, Jakarta, 1987.

h. Yahya Harahap, Segi-segi Hukum Perikatan, Alumni, Bandung, 1986.

\section{Daftar Peraturan Perundang-Undangan:}

a. Undang-Undang Dasar Republik Indonesia Tahun 1945

b. Kitab Undang-Undang Hukum Perdata 